\title{
Going Global, Acting Local: Effects of Cultural Dimensions on Glocal Marketing in Malaysia
}

\author{
Samira Khalili \\ Putra Business School, University Putra Malaysia \\ 43400 UPM Serdang, Selangor, Malaysia \\ Email: Samira.khalili@gmail.com
}

\begin{abstract}
The present research investigates the effects of Malaysian cultural dimensions on promotional activities and advertisement styles of international organizations in Malaysia. Website Content analysis has been conducted to discover what initiatives international organizations use in their marketing activities based on the Malaysian cultural dimensions. Results show most companies are considering values of 'collectivism and relationshiporientation', 'high context', 'religion' and 'hierarchism' as affecting factors, and apply approaches to fulfil the society’s cultural needs regarding their marketing practices.
\end{abstract}

Keywords: Globalization, Glocal Marketing, Culture, Online Marketing, Malaysia

\section{Introduction}

As Marshall McLuhan called it in 1989, we are now living in a "global village" (McLuhan, 1996). New technologies, information, and even tastes travel all around the world in a split second. This fact creates both opportunities and threats for industries in many diverse areas, such as operations, management and leadership styles, and marketing. The competition becomes huge and companies need to be aware of the strategies to stand out in a worldwide business. That is why the need of product modification, new distributions, and new promotional strategies emerge. Overcoming these challenges requires focusing on the local customs and conditions of each region. More specifically, international companies and marketers should take advantage of different cultures as they play an important role in consumers' perception towards preferences in purchasing a product or service (Shafi et al, 2014; Lim \& Park, 2013). Failing to do so can put any effective marketing plan go astray.
Malaysia, located in a strategic position in the South East Asia, has a relatively open market to the world. The number of companies entering Malaysia to serve the market has grown over the years; therefore, the need to know the best practices of gaining the market is essential. Comprising different ethnic groups - Malays, Indians, Chinese- and a wide range of religious -Islam, Buddhist, Christian, and Hindu-, Malaysia would be considered among the multinational countries with different cultural issues. An international marketer must take this diversity into account. For example, Muslims poorly receive advertisements about alcohol or pork products while Chinese accept them. Thus, it can be perceived that Malaysia's cultural dimensions should be considered in marketing of global products and services in the country.

One of the main reasons for the differences occurring from market to market is "culture". People are not different from each other; it is the cultures that teach us to separate traditions and beliefs (Browaeys and Price, 
2008). Therefore, the effects of local culture are far more complex. In todays' world, the consumers from all around the world with different cultures want marketing messages to keep the global standards and at the same time make a local sense. Here is where the emergence of defining the word 'glocalization' occurs (Lim \& Park, 2013). Glocalization is the combination of the two words of globalization and localization. This combination defines a product or service improved and distributed globally while is fashioned to accommodate the consumer in a local market (Foglio \& Stanevicius, 2006, Cannon \& Yaprak, 2014). Glocalization concerns the local laws, traditions, culture, practices and the system of values. By glocalization, organizations can help consumers to have a local understanding of a product.

Many firms that are entering new markets or performing in existing markets are aware of the emergence of paying attention to the local attributes. These attributes are surely defined by many characteristics. This research intends to particularly study those attributes that are specifically defined regarding Malaysia's society. These dimensions are 'Collectivism and relationship orientation', 'high context', 'hierarchism', and 'religion' (Abdullah, 2005). The main purpose of this research is to identify what are the effects of these dimensions on the methods international companies conduct web based marketing in Malaysia; and also to exhibit how these dimensions affect their promotional activities and advertisement styles. The research aims at answering the following questions:

1. What cultural dimensions have major effects on successful marketing communication in Malaysia?

2. How do these dimensions affect glocal marketing content in Malaysia?

3. In what ways could companies modify their glocal marketing strategies from the results of this research to match these effects?

Naturally, not all dimensions which will be discussed in the literature-collectivist and relationship-oriented, high context, religious, hierarchical, face saving, pursuit of success- are expected to have an impact on marketing adaptation strategies and consequently, to be visualized and presented in web pages. As a result, the attempt of this research is to explore the effect of the most important Malaysian cultural dimensions, which are related to marketing and more specifically, to the way international companies are adapting to Malaysian culture.

\section{Literature review}

\subsection{Globalization}

The term 'Globalization' was hardly used before the late 1980s and has been popularized in less than a decade. Globalization is fundamentally social, cultural, and political, not just economic (Cannon \& Yaprak, 2014, Giddens, 1999). Generally, it carries the core meaning of 'all people on earth living in a single social space' in light of Marshall McLuhan's notion of a "global village" (McLuhan, 1996, p21). Even though this term has been utilized a lot recently, "Globalization of the Markets", under its present way, is used first by Levitt in an article in the Harvard Business Review in 1983 (Levitt, 1983, p2-20).

Globalization would result into a new commercial reality, as differences in national preferences in consumption transactions would disappear; and this would lead to a pure standardization of products, operations, and marketing (Shafi et al, 2014). In his "Globalization of the Markets", Levitt (1983) proclaims "a new commercial reality” based on the "emergence of global markets for standardized consumer products on a previously unimagined scale” (p. 15). He argues that "accustomed differences in national or regional preference or ancient differences in national tastes or modes of doing business" are gone (p. 17). What he suggests instead of them is a "commonality of preference which leads inescapably to the standardization of products, manufacturing, and the institutions of trade and commerce” (p. 18-19).

The main point for this anti-globalization stand is based on the local differences in taste, which directly or indirectly influences the process of consumption decision-making. Arnold (2004, p. 95) emphasizes that the major problem of international marketing is that the global presence of companies and their brands are increasing and yet the consumers' are retaining their local orientation in terms of tastes and demands. Lindstorm (2006, p. 20) also states that "the global-only 
campaign does not exist”. This is a further sign for the failure of Levitt's prophecy of the globalization of markets and universal standardization.

\subsection{Standardization, Localization or Glocalization?}

Companies intending to go global would find their path to international markets only through the help of a careful planning and effective execution. In regards to this, standardization can happen in the product mix for a 'global consumer', as global consumers prefer standardized, low-priced, quality goods (Shafi et al, 2014; Usunier, 1996). Miracle, Taylor, and Chang (1992) are aware of its importance and brought along a clear definition of standardization. Standardization is referred to as the use of a common approach (e.g. advertising message) and/or elements and appeals (e.g. strategy, execution and language) in an advertising campaign across national boundaries.

The problem arises when one considers that the consumption of a standardized product might be similar in different countries, but the way to persuade the consumer to choose those products is different (Prakash \& Singh, 2011). These differences are due to various factors among which we can mention: political, economic, legal, social and cultural. It has been realized by researchers that complete standardization over several countries is nearly impossible because of at least language differences between countries and the difficulties it arises. Arnold (2004, p. 11) points out that ruling out local factors and homogenizing individual tastes "would be swimming against the tide of marketing and is likely to fail". Many worldwide businesses are moving more and more towards this chant. It is in regards to this opposition that the phrase “Think Globally, Act Locally” emerges.

However, it should be kept in mind that universal localization does not exist either. Regarding this, Robertson (1992) introduces the term 'glocalize' which coined by Japanese and used mainly in business area a combination of global strategy and local adaptation, which was an attempt to understand two contradictory streams (Prakash \& Singh, 2011).

\subsection{Culture and Glocalization}

Culture is complex and composed of visible and invisible variables (Lim \& Park, 2013; Cannon \& Yaprak, 2014). Indeed, marketers must take time to learn about the culture of their customers to target their fundamental needs. Therefore, there is the need to interpret the culture in relation to marketing (Lim \& Park, 2013). Although it is complex to present a precise definition for culture, there are many attempts to define this term. Among all the definitions, Hofstede's (1984) definition of culture seems to be the best known from many researchers' point of view (Mead, 1998). Hofstede (1984, p. 51) defines culture as:

"The collective programming of the mind which distinguishes the members of one human group or category of people from another Culture, in this sense, includes systems of values; and values are among the building blocks of culture".

Culture, in relation to international marketing, is defined as "the sum total of learned beliefs, values and customs that serve to direct consumer behaviour in particular country market” (Doole \& Lowe, 2001, p. 85). Usunier (1993) believes culture has three essential components:

- Beliefs: A large number of mental and verbal processes reflecting our knowledge and assessment of products and services.

- Values: The indicators consumers use to serve as guides for what is appropriate behavior. They tend to be relatively stable and enduring over time and widely accepted by members of a particular market.

- Customs: Modes of behaviour that constitute culturally approved or acceptable ways of behaving in specific situations. Customs are evident at major events in one's life like birth, marriage, death, and at key events in the year like Christmas or Easter.

These components directly affect consumption behaviours and patterns of purchase. They send messages to the consumer about the selection of the good or service. However, Doole and Lowe (2001) define eight other characteristics of culture, which form an easy understanding framework for examining a 
culture from a marketing perspective. These characteristics are: religion, values and attitudes, education, social organization, technology and material culture, law and politics, aesthetics, and last but not least, language. One framework for a clear understanding of the influence of culture on international marketing is the Hofstede's (1983) five cultural dimensions; Power Distance Index (PDI), Uncertainty Avoidance Index (UAI), Individualism (IDV), Masculinity (MAS) versus its opposite femininity, and Long-Term Orientation (LTO) versus Short Term Orientation. According to him the way people in different countries perceive and interpret their world varies along these dimensions. Another framework to understand culture is what Hall (1960) introduces: high and low context cultures. Higher context cultures prefer using high-context messages over low-context messages in routine communication. Low-context cultures rely on spoken and written language for meaning while High-context cultures use and interpret more of the elements surrounding the message to develop their understanding of the message. In high-context cultures, knowledge and the social importance of the person add extra information to the message; and this will be perceived by the messagereceiver. Since this research focuses on the cultural dimensions of Malaysia and their effects on marketing activities, especially on promotion of international companies, there is a crucial need to study Malaysian cultural dimensions.

\subsection{Malaysian Culture}

Malaysians are from many different ethnic origins. Over the years, each of these ethnic groups has been able to keep its own unique culture and they all live in harmony in multicultural Malaysia. Abdullah (1996) points out that while Malaysians differ in many symbolic expressions, their common denominator lies in their deep-seated Asian values, some of which are "respect for their elders, collectivistic orientation, Harmonious relationships, a concern for face saving, and a religion orientation. At "intracultural level" they adopt a communication style that would enable them to relate with members of their ethnic groups. At "intercultural level" they want to build rapport and understanding between their own and other ethnic groups within Malaysia. At "cross-cultural level” they learn to communicate with foreigners.

In her book "Going Glocal: cultural dimensions in Malaysian Management”, Abdullah (1996) states that based on studies done by the Malaysian Institute of Management and other scholars on values, Malaysians, whether Malay, Chinese, Indian or others have the followings as values:

- Collectivistic: Malaysians tend to have a high concern for others, keep other people in mind, promote a sense of oneness with other people and consider the group as a basic unit of survival.

- High context: This means that both verbal massages and the circumstances surrounding the communication event are playing a role in interacting with others. More detailed information is often transmitted through continuous and imprecise, sometimes non-verbal formats among networks of friends and relatives.

- Hierarchical: In Hofstede's studies (1983) Malaysia is identified as having the highest power distance (the score is 104). This means that Malaysians are willing to accept the fact that inequality in power is considered normal. This also means that Malaysians would expect their elders to take the lead and be regarded as significant role models and "wise elders". Their authority is often unquestioned especially by their subordinates, for to do so would be considered as rude and improper on their part.

- Relationship-oriented: Malaysia has high context culture where it is not so easy to separate the person from the events surrounding him. Therefore, there is a need to build relationships before doing any business.

- Face saving: Another characteristic of high context cultures is the concept of face. It means keeping a person's dignity by not embarrassing or humiliating him in front of others.

- Religious: Most Malaysians identify with a particular religion. For all Malays, Indians, and Chinese, the religious practices are important sources of contentment and spiritual health, which affects their life style and decision-making processes. Malaysia's religious demographics are 
as follows: " $60.4 \%$ Islam, $19.2 \%$ Buddhism, 9.1\%

Christianity, 6.3\% Hinduism, and $2.6 \%$

Confucianism, Taoism and other traditional

Chinese religions” (Population and Housing

Census 2000).

\subsection{Managing Glocal Marketing across Cultures}

Literature shows that marketing across the world comes across the cultural concerns. This fact emerges the glocalization (Prakash \& Singh, 2011). It is obvious that the reflection of local cultural values helps in persuading the target market. Global marketers have long been confused with the question of in what situations, and to what extent marketing across national and regional borders must be "standardized", or "localized" for the market (Duncan \& Ramaprasad, 1995). There are a number of reasons for the need to glocalization. For example, in Asia, complex sociocultural, religious and geographical differences create many national markets within the region (Cannon \& Yaprak, 2014; Rothrock, 2004). It is the duty of global marketers to provide a respond to these complexities; however, this matching of marketing mix to local cultural differences is a difficult and fairly costly process.

In their study, Foglio and Stanevičius (2007) focused on the concept of marketing and glocalization. They applied the concept of marketing to the reality of the glocal market and the glocal enterprise, and then concluded that glocal marketing is:

- a way of leading the enterprise in its glocal market relations so that every decision can be taken in advance;

- the strategic integration of local and global marketing;

- the rational exploitation of the glocal market;

- an effort of planning aimed to maximize the chances offered by the glocal market;

- the set of the means at disposal of the enterprise in order to create, preserve, develop its glocal market;

- And the action aimed to intensify and improve the company's presence in the glocal market.

Based on what Foglio and Stanevičius (2007) present, the effective glocal marketing strategy should have some important characteristics:
- Localism: Global marketing relates to the "paneconomy” (everything becomes global economy), while glocal marketing has a strong roots in localism, local productions, and local demand.

- Glocal mentality: Because the trend is towards the glocal market, the marketing also must be supported by glocal mentality and justified by this belief of the existence of the glocal market and the necessity of adequate operations.

- Coordination: The marketing must become the coordination of all the business activities oriented to the glocal market. For being more effective the marketing variables, the policies, and the strategies must be coordinated.

- Effectiveness: Glocal marketing searches for particularities and concreteness, therefore it must be effective; the lack of effectiveness is a symptom of a wrong glocal marketing application.

- Interdependence: The interaction and the integration between localization and globalization make the glocal marketing interdependent in the relative supports related to it.

- Differentiation: Every glocal enterprise would have a personal and differentiated application of the glocal marketing; this differentiation could be a valid competitive advantage that is able to discover the appropriated segments which the glocal marketing tends to reach.

- Decentralization: The glocal marketing must respect the local characterization; therefore it must accept the decentralization (decisions and actions of the decentralized management, of distributors; and of importers).

Having identified the most important factors and components of cultures, and also glocal marketing characteristics, we can now look at what works are done regarding the adaptation of marketing mix. Many authors worked on the ways companies can overcome the issue of cultural differences.

Product standardization is an approach where a firm is able to export their products to international markets without any essential changes because of the similarities in taste and needs in global market (Onkvisit \& Shaw, 2004; Cannon \& Yaprak, 2014). Many companies develop a global product including regional and cultural differences and specifications to 
make the product acceptable in all countries. Hence, this is only effective when the host countries' cultures are close to the home country culture. Elements that have to be considered about product adaptation are design, brand names, packaging, and colour of the product (Keegan \& Green, 1999).

As another element of marketing mix, price is the sum of all the values that consumers exchange for the benefits of having or using a product or service. The decision to adapt or standardize the price depends on different factors that you can see in Figure 1 . Standardizing price means that the head office decides a fixed price that is applied in all international markets without taking in consideration the factors above. Standardized price is more used by companies in B2B market than in B2C market because they are less pricesensitive (Hollenson, 2001). When companies use this strategy, they take less risk, since as no attempt is made to respond to local conditions, no effort is made to maximize the profit neither (Hollenson, 2001).
A way for the company to have a greater success is to adapt the price to local conditions (Onkvisit \& Shaw, 2004). The adaptation should be made regarding the foreign consumer's revenues and it is sensitive to local conditions.

Then it comes to promotion, another element of marketing mix. Total promotion mix, also called marketing communications mix, consists of advertising, public relations, sales promotion, personal selling and direct marketing tools. Promotion also has to be adapted or standardized. This means whether to create such advertisements that would work in any given country and culture or something specific for each country (Prakash \& Singh, 2011; Keegan \& Schlegelmilch, 2001). The standardization of the promotion means that same promotion is used in all countries in the world without any changes (Onkvisit \& Shaw, 2004). However, because promotion is affected by religions, language, economic differences, laws and media availability, a need of adaptation for advertising messages occurs (Theodosiou \& Leonidous, 2002).

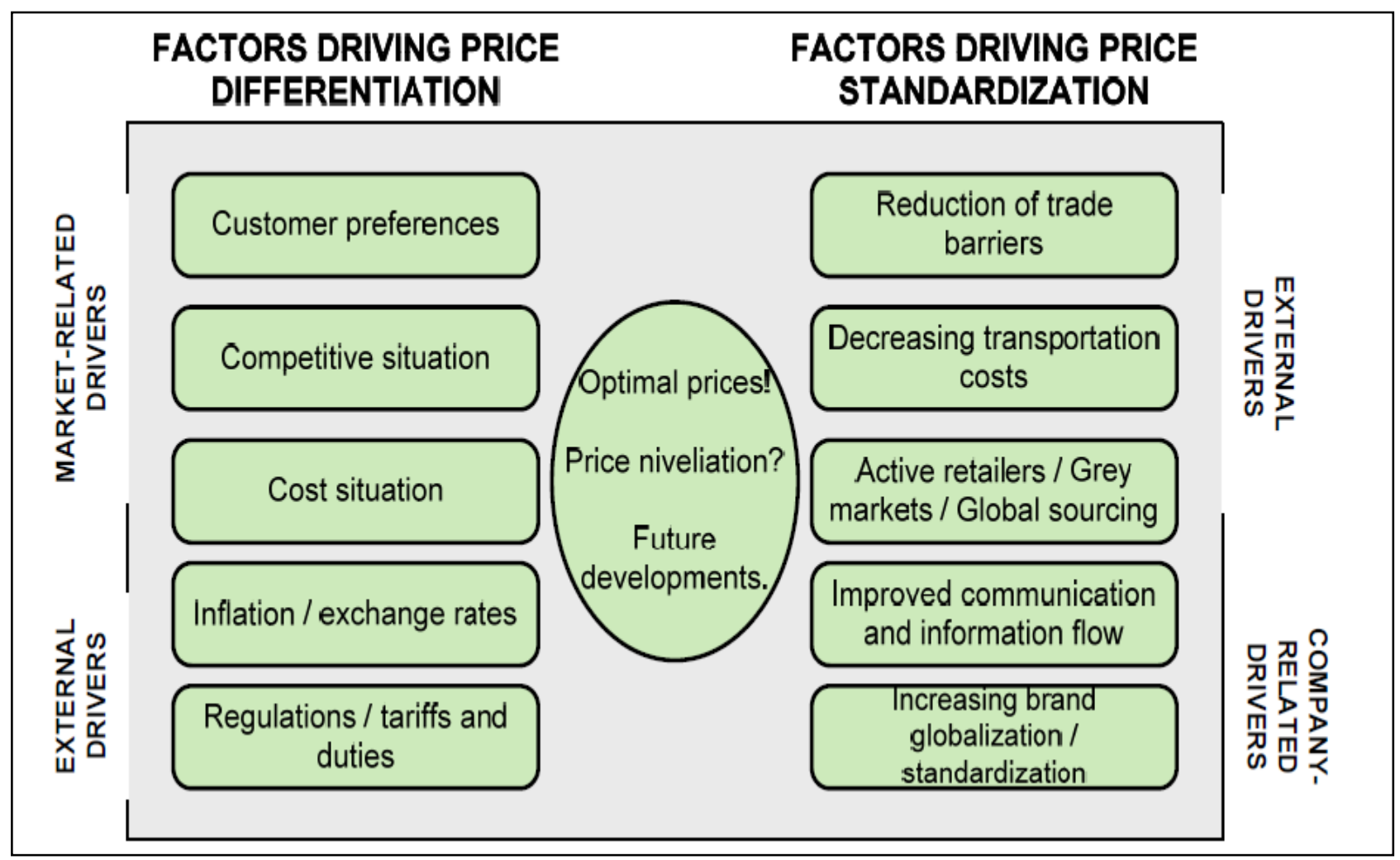

Fig.1: Factors Affecting the Decision to Adapt or Standardize Price (Keegan \& Schlegelmilch, 2001, p.408) 
Place or channel of distribution, according to Keegan and Green (1999) are defined as an organized network of agencies and institutions, which together perform all the activities required to link procedures with users to accomplish the marketing task. Distribution channels are the component of the international marketing mix that can be more adapted (Onkvisit \& Shaw, 2004). It is difficult to standardize channel distribution due to the very large variations in most of the countries. There are therefore different places of distribution as well. Place of distribution might be supermarkets of different sizes or small shops or even the Internet. Standardizing or adapting the distribution channels depends on several factors: customer, culture and the product. The degree of standardization or adaptation of the distribution channels depends on the country the firm is established (Gnizy et al. 2014; Onkvisit \& Shaw, 2004).

A glocal marketing mix is affected by cultural diversity, geographical factors as well as issues such as regulation, product use patterns, and socio-economic levels of development, education, language differences, and organizational structures (Gnizy et al. 2014, Duncan \& Ramaprasad, 1995). Consequently, promotional activities and advertisements also would be affected, especially in a country like Malaysia with various ethnic groups and religions.

Malaysia as the market we focus on, has its own cultural dimensions and values which were discussed thoroughly. All these dimensions should be considered if an international marketer intends to apply the glocal marketing approach.

\section{Research methodology}

\subsection{Research Approach: Qualitative}

As the purpose of this research is to investigate how Malaysian cultural dimensions affect the companies' decision to adapt or standardize their marketing activities, this study has used a qualitative case study approach. It should also be mentioned that, since this research plans to explain the influence of specific phenomenon on a particular market, it can provide a deeper explanation of data collection related to the problem as well as the findings through qualitative approach.

\subsection{Data Collection}

In this research, secondary data have been collected from literature regarding glocal marketing and culture. This data was found in the library of Universiti Putra Malaysia, Internet data bases such as Science direct and books with a clear link with the research purpose. Online research was the primary method to find related books. In one case, communicating and discussion with the author helped to gain more information needed. The key words were culture, globalization, glocalization, global marketing, glocal marketing, marketing strategies, standardization, adaptation, Malaysian marketing strategies, and Malaysian culture.

Moreover, secondary data about the case studies were found in the official website of the companies. Chapple and Moon (2005) believe that corporate websites are official representations of companies' policies. The same researchers and other authors such as Ho and Taylor (2007), and Williams and Ho (1999) believe that corporate websites are alternative mechanisms for disseminating corporate information. They allow a better two-way communication, circulation, unlimited space for reporting, lower costs of disseminating information, and uncontrolled access time (Tee, 2008).

\subsection{Reliability and Validity}

For this research to be reliable, all the resources and references are carefully chosen and stated. Thus, studies with the same data collection methods would reach similar results. However, for a qualitative study, validity is of a great importance than the reliability (Holme and Solvang, 1991). To make this research valid, the secondary data were obtained from a wide range of sources to increase the ability to compare the data to increase the accuracy and sufficiency of data.

\subsection{Data Analysis: Content Analysis}

In this research content analysis, which is used by many researchers (Sing and Baack, 2004; Sing, Kumar \& Baack 2005; Zahir, Dobing, \& Hunter, 2002) in the related literature of marketing and advertising, is used to study cultural value appeals. A content analysis framework is used to analyse the local cultural values portrayed on international companies' websites for marketing in Malaysia. Furthermore, many studies have 
used this type of analysis to study cultural value appeals in cross-cultural advertisements (Cho, Kwon, Gentry, Jun, \& Kropp, 1999).

For the purpose of this research, a number of different websites, from different sectors such as food industry (Nestlé, KFC, and Mc Donald's), automobile industry (Toyota), and banking (HSBC bank, Citibank) are used. There are also illustrations from other companies such as Sony and Burger King. The effects of cultural dimensions that are the most influential in Malaysians life styles -as mentioned earlier- are examined on the way international companies are applying their marketing activities and adapting their promotional styles in Malaysia.

\section{Analysis}

In order to gather data, the Malaysian websites of the international companies operating in Malaysia have been observed. These websites are then compared to the global websites of the same companies, and also their websites in other countries that have different cultural characteristics compared to Malaysia. The websites chosen for this purpose are in different industries. In the food industry, Nestlé, KFC, and Mc Donald's websites are observed; Toyota is chosen in the car industry; and HSBC bank and Citibank are chosen in the banking industry. There are also illustrations from other companies such as Sony and Burger King. Based on the gathered data, results were concluded on how international marketers adapt their original marketing strategies, promotional activities and advertisement styles to the Malaysian culture.

\subsection{Collectivism and Relationship-Orientation}

As Hofstede (1991) ranks Malaysia, this country has a collectivist culture where people from birth onwards are integrated into strong, unified groups and families. Malaysians, being relatively high collectivists, usually keep other people in mind and have a high concern for others. They tend to consider the group as a basic unit of survival. Individuals in a collectivistic society tend to participate more in in-group activities, be more concerned with in-group interests, and feel compelled to conform to in-group opinions (Hui \& Triandis, 1986). Therefore, Malaysians generally prefer togetherness. Considering Malaysia as a collectivist society which is also very relationship-oriented, Nestlé's website in Malaysia (www.nestle.com.my) contains some links which portray their attempts towards providing a relationship-oriented website. Having a "wellness greeting cards" link in their home page in 2010, which presented e-cards about different festivals in Malaysia as well, is a good demonstration of their caring about the importance of Malaysian collectivist nature (Figure 2). However this feature is no longer available in the website in 2014. Instead, in 2014, Nestlé attempts to provide relationship oriented activities for Malaysians to keep them in touch with the company the way the society prefers. Activities such as "Malaysia Walks Now" try to involve the target market in in-group activities (Figure 3). Links and activities as such cannot be found in Nestlé's website of more individualist countries such as the Nestlé USA neither

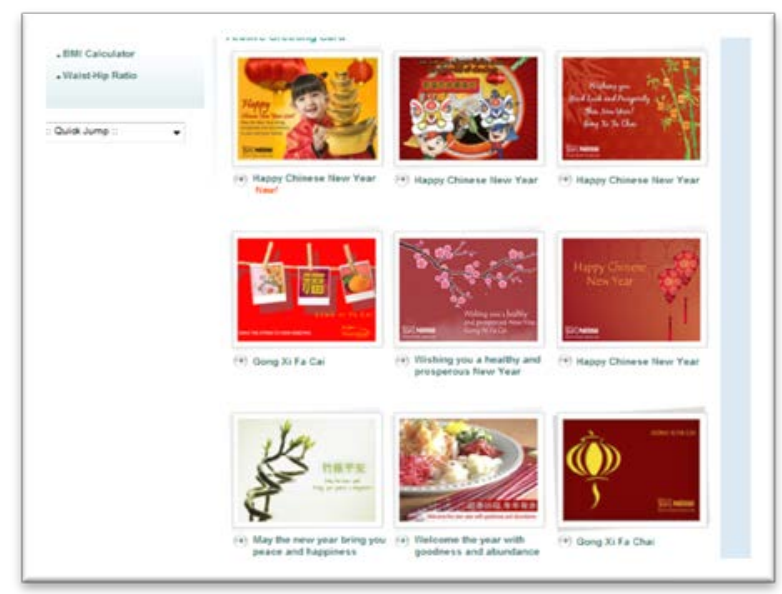

Fig. 2 Nestlé Wellness Greeting Cards link. Source: http://www.Nestle.com.my/fun+and+learn/wellness+gree ting+cards/(2010)

in 2010 nor in 2014; instead, do these countries websites contain more informational pages about nutrition and wellness.

In 2010, this attention to family and relationshiporientation of Malaysians could be also observed in the KFC's Malaysian website (http://www.kfc.com.my). Unlike other countries' KFC websites in that year (such as France - http://www.kfc.fr -, the USA http://www.kfc.com - or Australia's http://www.kfc.com.au -), that emphasized more on the 


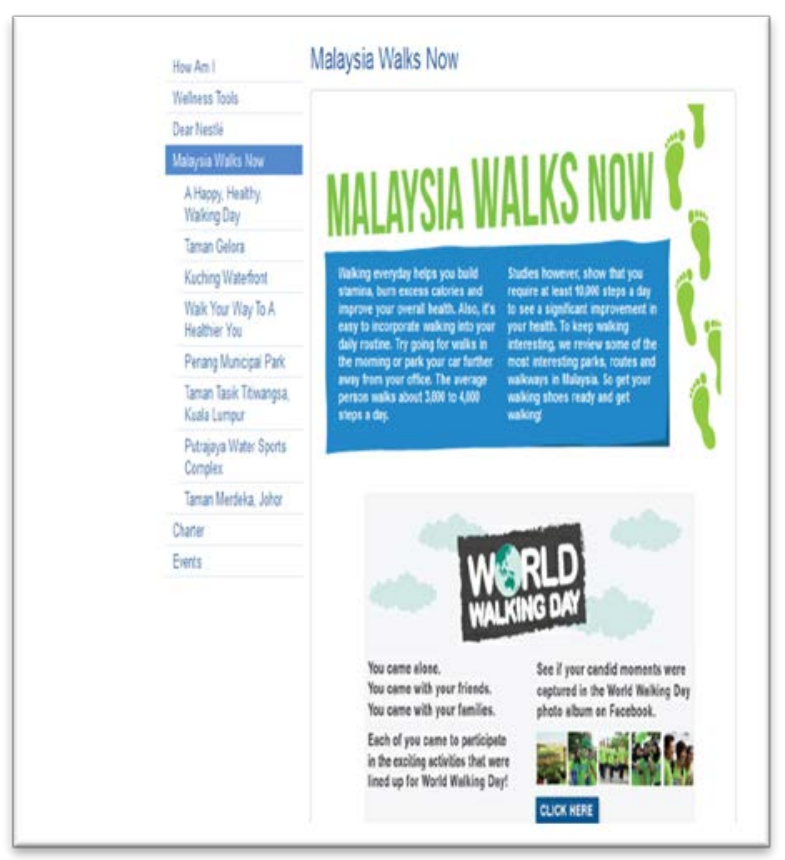

Fig. 3 Nestlé attempts for In-group activities in Malaysia. Source:

www.nestle.com.my/nutrition_health_wellness/malaysia_ walks_now (2014)

product and menus, this website contained a wide range of links related to family, teen, and kids' activities. Previously also, KFC had activities towards relationship-oriented promotion as well. In 2009 KFC had a campaign called "Good things come together with KFC" in which friendship and close relations were the main theme of the advertisement. Nevertheless, KFC website in 2014 does not feature any of these elements any longer, and is more alike other countries websites with more focus on menus, promotions and products.

Since unity, nation, and country are important to collectivists (Hofstede, 1991), paying attention to the national identity by providing picture and symbols is another proof that the company cares about the society's collectivistic characteristic. In 2010 McDonald's even provided a link in its Malaysian website named "Malaysian Stories". This link was about experiences of different McDonald's managers and other staff in an animation background of different Malaysia’s city symbols (Figure 4).

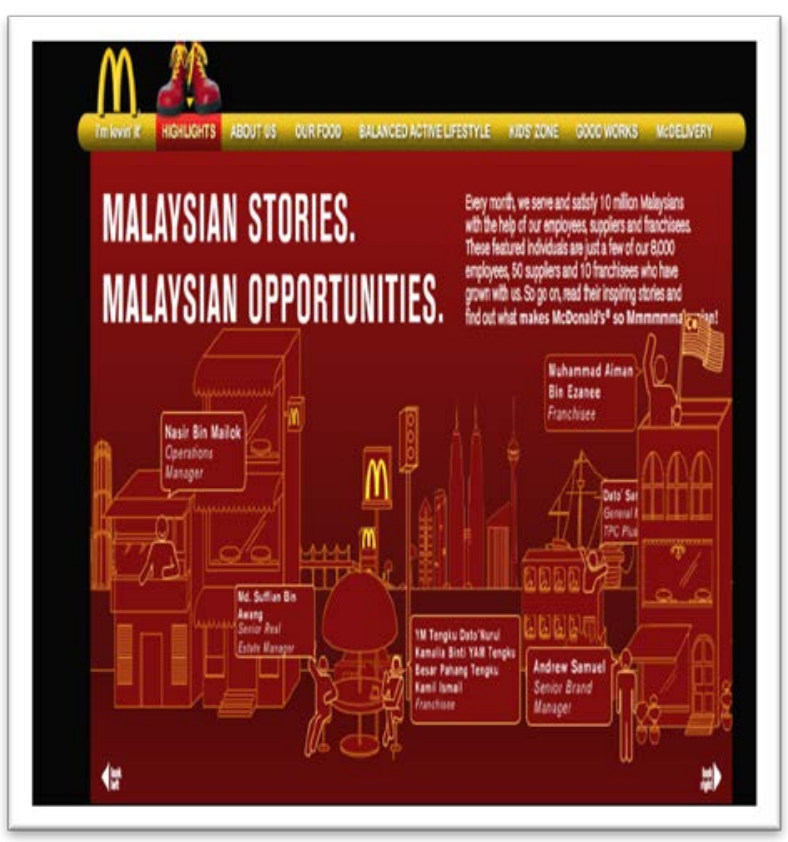

Fig. 4 Malaysian Stories of McDonald's Website. Source: http://www.mcdonalds.com.my/arcage/msiastories.asp (2010)

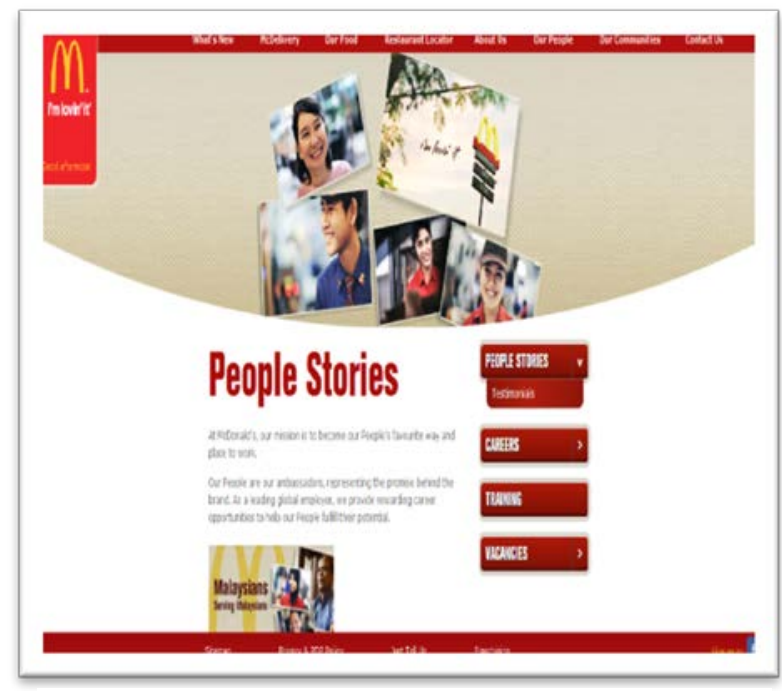

Fig. 5 Malaysian Stories of McDonald's Website. (2014)

Mcdonalds.com.my tends to have the same scenario in a different look in 2014. The new look is less Malaysian (Figure 5), and you could find same links in McDonalds Australia or USA websites.

Related to the same issue, Toyota Malaysia's website in 2010 (http://www.toyota.com.my/index.html) illustrated the same image as KFC in 2010. Twin 
towers and Menara KL are symbols of Malaysia all

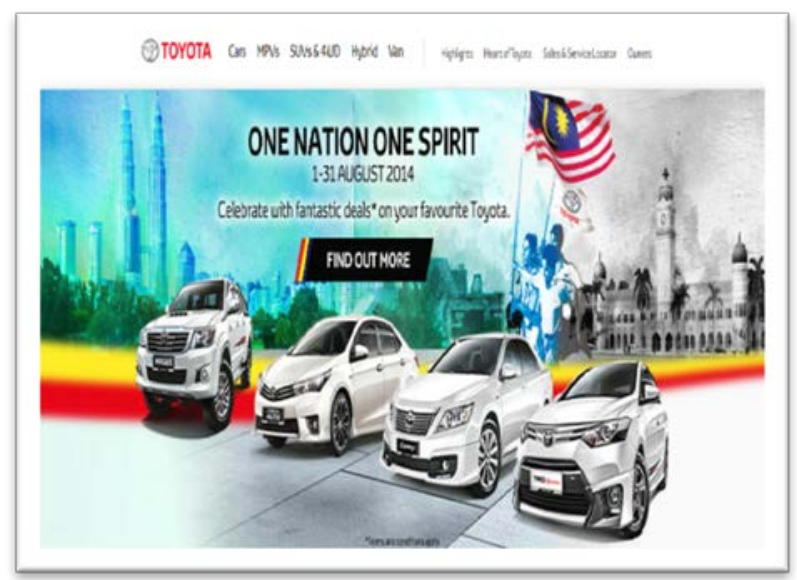

Fig 6: Toyota Malaysian Website (accessed 2010)

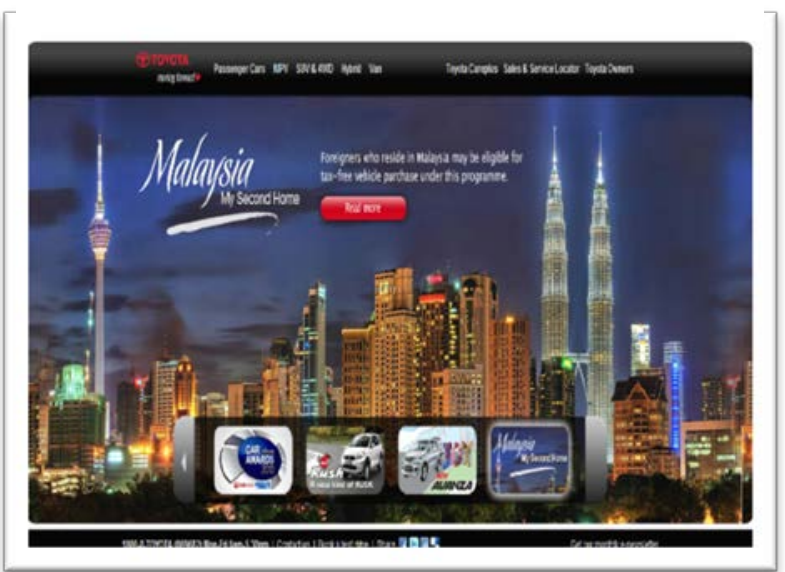

Fig 7. Toyota Malaysian website in 2014

around the world (Figure 6).

However, it is noticeable that this dimension also has been less appreciated by Toyota.com.my in 2014 as the website looks more standardized all through different countries' websites. Only some minor elements differentiate Malaysian website from other parts of the world website. Figure 7 shows the only picture of the website in 2014 that is of Malaysian Nature.

\subsection{High Context}

The importance of high or low context characteristics is due to its significant influence on choosing the correct approach to deliver the desired message. Based on what anthropologists and sociologists such as Hall (1976) and Abdullah (2005) believe Malaysia has a highcontext culture. This fact brings this notion along with itself that in Malaysia most of the information in the message is in the physical context or is internalized in the person, and only very little is in the coded (in form of words), explicit, and transmitted part of the message. Furthermore, signs and symbols are important means to accentuate certain meanings (Fink and Laupase, 2000). In this culture, what is said suggests a limited amount of the meaning, and instead how and where the message is being said, as well as the body language and the status of the speaker has a greater impact.

In 2010, this aspect of Malaysian culture was well demonstrated in overseas bank websites operating in Malaysia, such as HSBC bank (http://www.hsbc.com.my/1/2/HSBC-Bank-MalaysiaBerhad). The same thing was also observed in KFC Malaysia website. As it can be seen in Figure 8 and 9, to differentiate and become able to build relationship
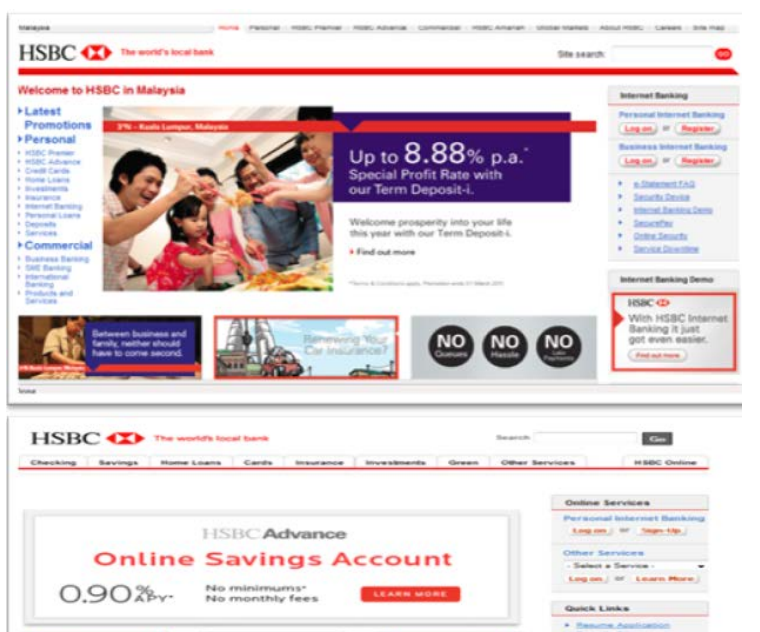

Fig 8. HSBC Malaysia use of Indirect Message Delivery through Images and Figures vs. HSBC Website direct approach in the USA

with customers, the layout of these websites relied mostly on nuances, pictures and other non-verbal cues.

In contrast, the same company websites in other lowcontext countries such as New Zealand or the USA in 2010 were completely different. The information in those websites, as shown in Figure 8 and 9, was conveyed directly and to the point. Few images were used and words were the main approach to explain 

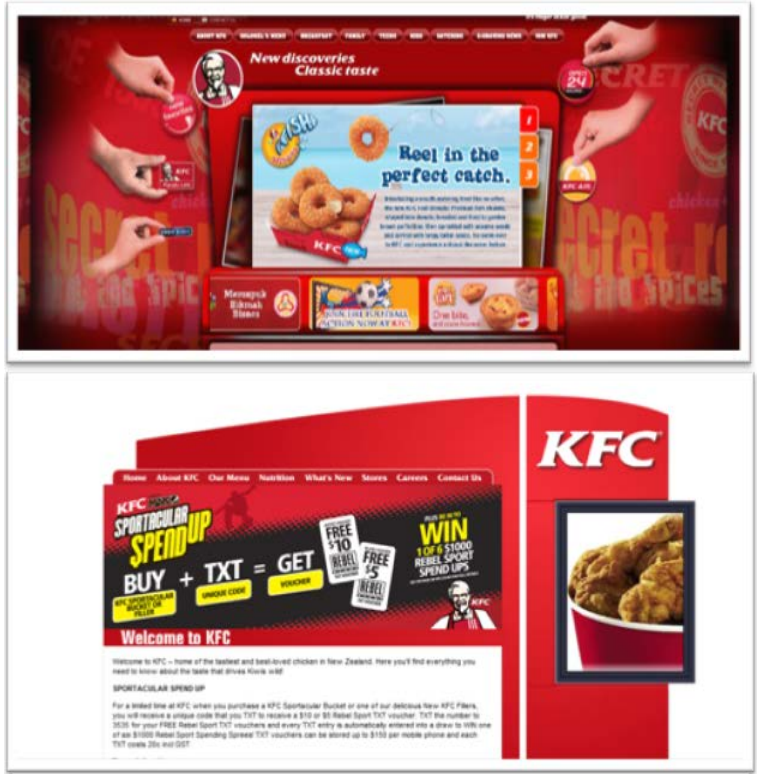

Fig. 9 Indirect Message Delivery in KFC Malaysia Website vs. Direct Approach of KFC Website in New Zealand.

about the features and to make sure the message is delivered as it was meant to.

In 2014, both KFC and HSBC Malaysian websites still keep the strategy of being high-contexter oriented as demonstrated in Figure 10.

In Malaysia, like any other high-context cultures, relationships must be built before doing any business. Moreover, "it is very difficult to separate business from Malaysians' private lives as they are often well integrated in the social fabric of ethnic-based relationships” (Abdullah, 2005).

\subsection{Religion}

Religious beliefs add another level of complexity to communicating marketing messages and they must be handled very carefully. When it comes to this cultural dimension, since Malaysia has a mixture of various ethnic groups and religions, an international marketer should pay a fair attention to the company's target market.

As the major religion and the official religion in Malaysia, Islam has a major implication on company's marketing in this country. Two most important factors to consider regarding this issue are, first, the stress on

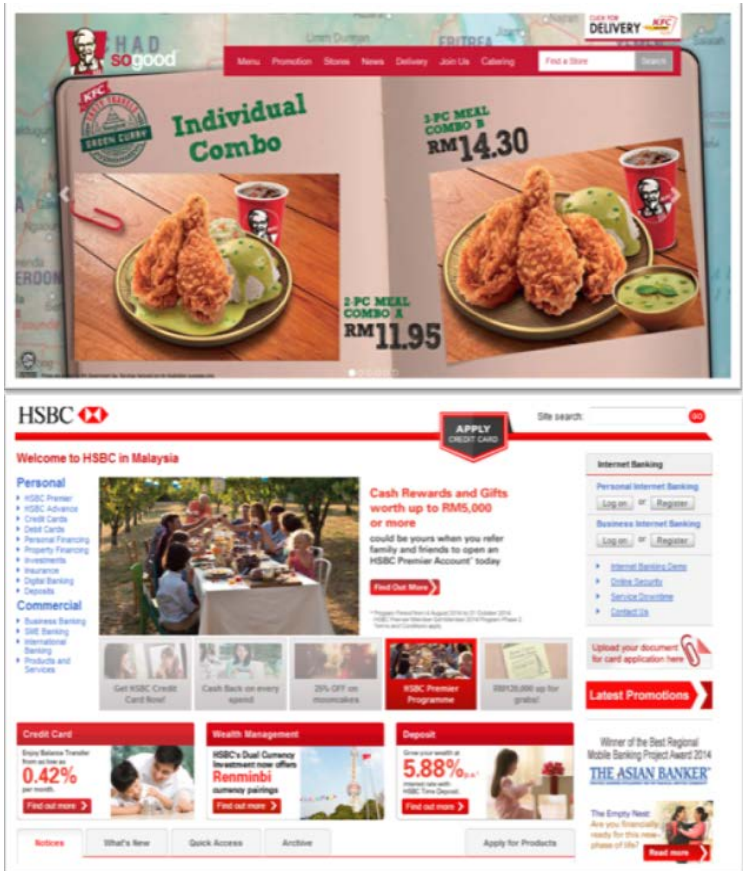

Fig. 10 Indirect Message Delivery in KFC and HSBC Malaysian Website. (2010)

the requirement for the food to be Halal, which means to be permitted by Islamic law, and second, the need to be sensitive to religious beliefs in advertisements, and the use of colours or words. One should also consider that gambling and alcohol consumption in Islam is prohibited.

Considering the importance of Halal industry in Malaysia - especially in food - KFC, Burger King, Nestlé, Tesco, Starbucks and so many other company websites have proofs of Halal certificates in their websites.

Apart from the limitations that Islam imposes on doing business and financing, the culture of having 'Halal' income is also strong in Muslim families. Muslim families tend to care about how they earn their salaries and in which industries they invest their money. Therefore, it is good for banks to provide a positive perception towards their financial activities for Muslim. Showing that their activities are accepted by Islam religion and it is safe for Muslims to engage in these activities can do this. When it comes to Malaysia (where the major religion is Islam) International bank websites, such as

HSBC 
(http://www.hsbcamanah.com.my/1/2/amanah/home), Citibank (http://www.citibank.com.my/english/islamicbanking/index.htm), and Alliance bank (http://www.allianceislamicbank.com.my/), provide a link for Islamic banking and financing.

\subsection{Hierarchism}

Malaysians, in general, accept the inequality in power and the level of people in the society. The value of respect for elders is an important aspect of societies with hierarchical culture. "Malaysians would be more likely to expect their elders to take the lead and be regarded as significant role models and wise elders” (Abdullah, 2005, p. 30). Based on the definition that Abdullah (2005) gives about 'hierarchism', we could conclude that 'hierarchism' matches the characteristics of 'power distance' that Hofstede (1991) points out.

As Marcus and Gould (2000) state a high power distance culture focuses on experts, certifications, official stamps and logos. Also a study by Singh and Pereira (2005) finds out that in a country in which hierarchy has an importance, certifications, awards and recognitions have this notion to the customers that the company's products are superior and have a better quality. Thus, for a country like Malaysia, websites may demonstrate this distinctiveness by the use of awards, certification logos and recognitions. They do this to both ensure their product quality is superior and also to respond to this cultural need of Malaysia. Malaysians prefer to have demonstration that the product is recognized. Moreover status of the people is considered as their importance and creditability. Special titles, pictures of important people in the company, organizational charts, and also company hierarchy information are displayed in appropriate situations. Doing this helps to convey needed messages and also to show the respect to the hierarchical positions. The reflection of Malaysian intention to accept the difference in power over members of the society is mostly evident in national websites, such as universities' websites (e.g. www.upm.edu.my). However, most of the international websites (Such as Nestlé and HSBC) devote a section to show the management's and president messages, as well as the organizational charts, awards and recognitions. But some other websites such as Toyota and KFC have decided not to mention these items in their website.

\subsection{Analytical Discussion and Conclusion}

The Malaysian culture determines the way people think and position. The empirical findings and observations show that the culture could influence the way international companies do marketing in Malaysia. Table 4.1 summarizes the empirical findings.

Table 1. Summary of the Empirical Data

\begin{tabular}{|c|c|}
\hline $\begin{array}{c}\text { Culture } \\
\text { Dimension } \\
\end{array}$ & Adaptation Attempt \\
\hline Collectivism & $\begin{array}{l}\text { Focusing on relationship closeness, } \\
\text { family activities and group loyalty. } \\
\text { Usage of national identity symbols } \\
\text { to make Malaysians proud as a } \\
\text { unified group. }\end{array}$ \\
\hline High context & $\begin{array}{l}\text { Indirect approach in message } \\
\text { delivery. } \\
\text { Usage of metaphors, signs and } \\
\text { animations. } \\
\text { Relationship building. }\end{array}$ \\
\hline Religion & $\begin{array}{l}\text { Focusing on the target market's } \\
\text { religious characteristics. } \\
\text { Considering Islam as the main and } \\
\text { major religious in Malaysia, such as } \\
\text { getting Halal certificate especially } \\
\text { for food and cosmetic industry, and } \\
\text { providing Islamic services such as } \\
\text { Islamic finance and banking. }\end{array}$ \\
\hline Hierarchism & $\begin{array}{l}\text { Demonstrating the difference in } \\
\text { levels of power. } \\
\text { Usage of both Figures and } \\
\text { statements of higher status persons. } \\
\text { Focusing on respect to elder } \\
\text { persons. } \\
\text { Demonstration of valuable } \\
\text { certificates and awards in promoting } \\
\text { strategies. }\end{array}$ \\
\hline
\end{tabular}


As stated before, not all the cultural dimensions affect the methods of marketing, promotion and advertisements. All the same, not those that affect the marketing methods, have the same importance and weight. Findings showed that the most important cultural dimensions affecting the marketing activities of international companies in Malaysia are the characteristics of collectivism, being high-context, hierarchism and religion. It is vital for companies to make sure they have considered these aspects when they are applying their international marketing strategies.

International companies which are originally from individualistic societies such as the United State, the United Kingdom, or Germany, should be totally aware of huge differences between the way they communicate, and the way they should formulate effective marketing plans in Malaysia. To create marketing plans for Malaysia, international marketers should take to account Malaysian cultural characteristics, such as the way they portray their body language and facial figure in delivering their messages. Moreover, it is important for international marketers to be aware of the potential restriction they may face when marketing in Malaysia, particularly those related to religious aspects. This also indicates that companies could launch new products or services designed for Malaysia taking into consideration religious aspects.

Findings support the need to adapt cultural values when marketing in overseas countries. However, in reality, it is not a must to adapt all the marketing strategies to all aspects of local market fully. A company has to choose the degree of adaptation based on the cost effectiveness of that adaptation. However, it is obvious that culture affects both the marketing strategies and the degree of adaptation.

\section{Conclusion}

As presented in the literature review, as well as in the analysis chapter, the more commonly discussed issues about the Malaysian culture are the value of 'collectivism and relationship orientation', 'high context', 'hierarchism', and 'religion'. Each of these values has impacts on the way firms do marketing activities in Malaysia.

\subsection{Key findings and research implications}

Being collectivists, Malaysians tend to be attracted to whatever makes them feel unified. Therefore, as a practical implication of the finding, it is wiser for international marketers to emphasize on social goals of their firms among Malaysians, as well as to provoke a sense of national or group unity, such as supporting the slogan of "One Malaysia” or using any other symbol of their national identity (such as Twin Towers). Due to this characteristic of collectivism and relationship orientation of Malaysians, the image of a company and the level of the trust the customer can build with the company is very important to them; people in Malaysia take a relative long time to develop relationships with a company and consequently it takes them a lot of time to be able to trust them. Thus, international marketers should pay more attention to building relationships with customers. This might happen through emphasizing on the usage of the firm's product or service by the famous people the society trust. This also may be built through providing some clubs or virtual places for customers to join and express their ideas or suggestions or even feelings about the company, its products, and its services.

High context, as another Malaysian characteristic, makes marketers take some clues and rules into account. For instance, the advertisements for Malaysian audiences are better to be written in indirect and impersonal styles. Symbols and images are the most attractive appeals in Malaysia, whether related to the products, services, or the company itself. For example, HSBC bank and KFC are using this method in their Malaysian websites.

Religion also plays a vital role in most of the Malaysians lives and Malaysia is considered as a relatively religious country. International marketers in Malaysia toned to care about the religion of the product or service target group. As the majority (around 60\%), Muslims play a major role. This fact has even affected the government rules and regulations. The promotions, advertisements, products and services, and even the place of distribution should meet the Muslims' requirements. Obtaining a Halal certificate is nearly a must in Malaysia especially for food and cosmetics. 
This has been done by KFC, McDonalds, L'Oreal and so many other companies.

A strong hierarchical system in Malaysia forces companies to provide organizational information for the Malaysian customer. Knowing the person in charge, and the international awards, certificates and recognitions of the company are issues to consider when doing marketing activities in Malaysia. If the company provides such information for its customers, the basis for a long lasting relationship would be built.

Understanding the customers' culture in Malaysia along the dimensions discussed in this study points out the way of international marketers toward specific adaptations necessary for an effective marketing strategy in Malaysian culture. This study aims at providing useful information for companies to adapt their marketing activities to Malaysian society in order to improve their market share and increase their benefits.

\subsection{Limitations of the Study}

This research observes and uses various international organizations' websites. However, the quantity of websites analysed might not be adequate to draw up general conclusions. Nevertheless, the important features related to cultural differences and their impacts on marketing activities in a number of websites were explored and analysed.

\subsection{Recommendations for Further Research}

The research scheme gives various other avenues for further studies. As the study was relatively small, a larger scale study can be conducted which considers more detailed cultural dimensions. In a country such as Malaysia, with a variety of subcultures, for a better understanding of the effect of cultural values on marketing activities, it is needed to explore more dimensions of culture, specifically in each of the ethnic groups. This is mainly because the target market may vary from product to product. For example some food products are only designed for some special ethnic groups and so on. Therefore, the study needs further expansion by applying more various sub-cultural dimensions.
Apart from only the website assessment, the complexity of Malaysian culture suggests multiple channel data assessment in order to have better understanding of how marketing strategies change in Malaysia. Any future research in this area needs to choose an appropriate methodology to assess the relationship between culture and glocal marketing. This could happen by conducting interviews or comparing the marketing plans of several different international organizations operating in different sectors in Malaysia.

\section{References}

1. Abdullah, A. (1992). The Influence of Ethnic Values on Managerial Practices in Malaysia”,Malaysian Management Review, Vol: 27, No.1 page 30

2. Abdullah, A. (2005). Going Glocal: Cultural dimensions in Malaysian Management, Malaysian Institute of Management.

3. Browaeys, Marie-Joelle \& Price R. (2008). Understanding cross-cultural management, Pearson education.

4. Cannon, H. M., \& Yaprak, A. (2014). Cosmopolitanbased cross national segmentation in global marketing simulations. Developments in Business Simulation and Experiential Learning, 28.

5. Chapple,W., \& Moon, J. (2005). Corporate Social Responsibility in Asia: A Seven-Country Study of CSR Web Site Reporting. Business \& Society.

6. Cho, B., Kwon, U., Gentry, J. W., Jun, S., \& Kropp, F. (1999). Cultural values reflected in theme and execution: A comparative study of U.S and Korean television commercials. Journal of Advertising.

7. Citibank Malaysia, retrieved in February 2011 from www.citibank.com.my

8. Cohen, M. (2002). Bridging the Great Divide. Far Eastern Economic Review

9. Denscombe, M. (1998). The Good Research Guide: for small-scale social research, First edition. Buckingham: Open University Press

10. Doole, I. \& Lowe, R. (2001). International MarketStrategy: Analysis, Development and Implementation, Thomson Learning, 3rd Ed.

11. Douglas, S. P. \& Wind Y. (1987). The Myths of Globalization. Columbia Journal of World Business, p. 19-29.

12. Duncan, T., \& Ramaprasad, J. (1995) Standardized multinational advertising: The influencing factors. Journal of Advertising, XXIV(3), Fall, 55-68.

13. Fink, D., \& Laupase, R. (2000). Perceptions of website design characteristics: A Malaysian/Australian comparison. Electronic Networking Applications and Policy

14. Foglio, A. and Stanevicius, V. (2006) Scenario of glocal marketing as an answer to the market globalization and localization. Part I: Strategy scenario and market, Vadyba/Management, p.26-38. 
15. Giddens, Anthony (1999). Runaway World: How Globalization is Reshaping Our Lives. London

16. Gnizy, I., Baker, W. E., \& Grinstein, A. (2014). Proactive learning culture: a dynamic capability and key success factor for SMEs entering foreign markets. International Marketing Review, 31(5), 2-2.

17. Hall, E.T. (1960). The silent language of overseas business, Harvard Business Review, May-June, p. 8896.

18. Hall, E. T. (1976). Beyond culture, New York: Doubleday.

19. Ho, L.-C. J., \& Taylor, M. E. (2007). An empirical analysis of triple bottom-line reporting and its determinants: Evidence from the United States and Japan. Journal of International Financial Management \& Accounting.

20. Hofstede G. (1984). Culture Consequences: International Differences in Work-Related Values, abridged edn. Thousand Oaks CA: Sage Publication Inc. McGraw Hill.

21. Hofstede, G. (1994). Management Scientists are Human, Management Science, p. 4-13.

22. Hollensen, S. (2001). Global Marketing, 2nd. Edition, Prentice Hall.

23. Holme, I. \& Solvang B. (1991). Forskningsmetodik Om Kvalitativa och Kvantitativa Metoder. Studentlitteratur, Lund.

24. HSBC Amanah, retrieved in February 2011 and August 2014 from www.hsbcamanah.com.my

25. HSBC Malaysia, retrieved in February 2011 and August 2014 from www.hsbc.com.my

26. HSBC USA, retrieved in February 2011 and August 2014 from www.us.hsbc.com

27. Hui, C. H. \& Triandis, H. C. (1986). Individualismcollectivism: A study of cross-cultural perspectives. Lincoln: Nebraska University Press.

28. International Forum on Globalization, San Francisco: The IFG, retrieved in January 2011 from http://www.ifg.org/analysis.htm .

29. Keegan, J.K. \& Green, S.M. (1999). Global Marketing, 2nd edition: USA.

30. Keegan, J.K. \& Schlegelmilch, B.B. (2001). Global marketing management - A European Perspective. Ashford Colour Press Ltd., Gosport.

31. KFC, retrieved in February 2011 and August 2014 from www.kfc.com

32. KFC Australia, retrieved in February 2011 and August 2014 from www.kfc.com.au

33. KFC McDonald's Malaysia, retrieved in February 2011 and August 2014 from www.mcdonalds.com.my

34. KFC New Zealand, retrieved in February 2011 and August 2014 from www.kfc.co.nz

35. Kotler, P., Wong, V., Saunders, J. \& Armstrong, G. (2008). Principles of Marketing.

36. Lee, J. A. (1966). Self reference criteria was originally coined Cultural Analysis in Overseas Operations, Harvard Business Review.

37. Levitt, T. (1983). The Globalization of Markets, Harvard Business Review, p.2-20.

38. Lim, H., \& Park, J. S. (2013). The effects of national culture and cosmopolitanism on consumers' adoption of innovation: A cross-cultural comparison. Journal of International Consumer Marketing, 25(1), 16-28.

39. Marcus, A., \& Gould, E. W. (2000). Cultural dimensions and global web user interface design: What? So what? Now what? In the 6th International conference on human factors and the web. Austin.

40. Mead, R. (1998). International management: Cross cultural dimensions. Oxford: Blackwell.

41. Miracle, G.E., Taylor, C.R. and Chang, K.Y. (1992). Culture and advertising executions: a comparison of selected characteristics of Korean and US television commercials, International Marketing Review, Vol. 9 No. 4 ,

42. Nestlé Malaysia, retrieved in February 2011 and August 2014 from www.nestle.com.my

43. Onkvisit \& Shaw, S. \& Shaw, J.J. (2004). International marketing - Analysis and strategy, 4th European Editon.Kapferer, J.-N. (1992) ESOMAR Seminar, In how global are global brands? The Challenge of Branding Today and in the Future.

44. Paul, F. \& Eriksson, L. (1997). Att utreda, forska och rapportera. Liber ekonomi.

45. Prakash, A., \& Singh, V. B. (2011). Glocalization in Food Business: Strategies of Adaptation to Local Needs and Demands. Asian Journal of Technology \& Management Research, 1(1).

46. Robertson, R. (1995). Glocalization: Time-space and Homogeneity and heterogeneity, M. Featherstone et al (ed) Global Modernities, London: Sage.

47. Rijamampianina, R. (1996). Effective Management in Multicultural Organizations, Economic Journal of Hokkaido University, 25, p. 119-167.

48. Robertson, R. (1992). Globalization: Social Theory and Global Culture, Sage Publication

49. Robertson, R. (1995). Glocalization: Time-space and Homogeneity- heterogeneity, M. Featherstone et al (ed) Global Modernities, London: Sage. p. 25-44

50. Rothrock, V. (2004). Culture Clash. Campaign, 16 July, 31.

51. Selfridge, R.J. \& Sokolik, S.L. (1975). A Comprehensive View of Organizational Development, MSU Business Topics.

52. Shafi, S. I., \& Madhavaiah, C. (2014). Impact of Promotional Activities on Brand Equity in Selected Apparel Brands: Evidence from India. Asia-Pacific Marketing Review, 59.

53. Sing, N., Kumar, V., \& Baack, D. (2005). Adaptation of cultural content: Evidence from B2C e-commerce firms. European Journal of Marketing.

54. Singh, N., \& Pereira, A. (2005). The culturally customized web site: Customizing websites for the global marketplace. Oxford: Elsevier Butterworth Heinemann.

55. Tai, S. H. C. (1997). Advertising in Asia: Localize or regionalize? International Journal of Advertising, 16, p. 48-61.

56. Tee. K. K. (2008). Corporate Social Reporting in Malaysia, (Doctoral Thesis) The university of Waikato, Hamilton, NewZeland. 
57. Theodosiou, \& Leonidou, M. \& Leonidou, L. (2002). Standardization versus adaptation of international marketing strategy: an interactive assessment of the empirical research. International Business Review, Vol.12, p. 141-77.

58. Toyota Malaysia, retrieved in February 2011 and August 2014 from www.toyota.com.my

59. United Nations, United Nations Development Programme, Human Development Report 1999 (New York, Oxford University Press), p. 25.

60. Usunier, J.C. (1993). International marketing: A cultural Approach.

61. Usunier, J.C. (1996). Marketing across Cultures. Englewood Cliffs: Prentice Hall.

62. Waller, D. S., Kim S. F, (2000). Cultural values and advertising in Malaysia: views from the industry, Asia Pacific Journal of Marketing and Logistics, Vol. 12.

63. Williams, S. M., \& Ho, C.-A. W. P. (1999). Corporate social disclosure by listed companies on their websites: An international comparison. The International Journal of Accounting.

64. Zahir, S., Dobing, B., \& Hunter, M. (2002). Cross cultural dimensions of internet portals. Electronic Networking Applications and Policy. 